\title{
A Study and Analysis of Investment Banking and Regional Development Among European Economy
}

\author{
http://doi.org/10.21272/fmir.5(2).107-113.2021
}

J. Jose Prabhu, ORCID: https://orcid.org/0000-0002-9816-119

Dr, Independent Researcher and Visiting Professor, Management and Engineering Colleges *(Freelancer), Tamil Nadu, INDIA

\begin{abstract}
Investment banks are financial intermediaries that specialize in the sale of securities and the issuance and underwriting of new shares to raise capital financing. Investment banking is a special segment of banking that assists individuals or organizations to raise capital in the main market. In the tea market, new securities are issued and act on behalf of customers, thus playing an important role in the secondary market. Investment banks undertake new debt or equity securities for all types of businesses, support the sale of securities, and facilitate mergers and acquisitions by institutional and individual investors. Investment banking organizations act as intermediaries between investors and capital markets. Investment banks are becoming important in European capital markets due to many factors including the perception of investment banks among investors and the various other functions implemented by investment banks. The research paper aims to show the role of investment banks in the current scenario. This study is descriptive in nature and uses auxiliary data. The study reveals the growth, development, function and role of investment banking in the European economy. The main objective of this investigation is to clarify how investment banks play a role in increasing a country's resources and economic growth. It analyzes the various functions performed by investment banks. Investment banks connect the people who sell securities with their investors. Investment banks add liquidity to the market. Investment banks promote savings and investment and eliminate capital shortages. Mobilize small, scattered savings in the community so you can invest in productive businesses. He concluded that the role of investment banks in economic development is important.
\end{abstract}

Keywords: Investment banking, economic development, organization development, European economy, investors relations.

JEL Classification: G15, G23, G24, G32, G41.

Cite as: Prabhu, J. J. (2021). A Study and Analysis of Investment Banking and Regional Development Among European Economy. Financial Markets, Institutions and Risks, 5(2), 107113. http://doi.org/10.21272/fmir.5(2).107-113.2021

Received: 1 May, 2021

Accepted: 3June, 2021

Published: 25 June, 2021

Copyright: (C) 2021 by the author. Licensee Sumy State University, Ukraine. This article is an open access article distributed under the terms and conditions of the Creative Commons Attribution (CC BY) license (https://creativecommons.org/licenses/by/4.0/)

\section{Introduction}

(EIB) The European Investment Bank is one of the most important donors of global climate change measures. The 2021-2030 decade is very important to solve the climate and an emergency on the environment of the planet. To achieve this, you have to invest in trillion. The European Union and the EIB team play a leading role in implementing the Paris Agreement. We set sustainability in the center of our activities.

For more than 50 years, EIB has been international development bank of the European Union. Our major investments worldwide create stability, sustainable growth to combat climate change anywhere.

In 2020, we invested around 10 billion euros in developed projects outside Europe. Africa loans increased by $50 \%$ to around 5 billion euros. We help the continent to strengthen the economy, support local companies, to combat climate change, promote innovation and construction of sustainable infrastructure. When you think of a bank, you can think of taking deposits and maintaining your checking and savings accounts. In fact, there are other types of banks that focus on equities, fixed income and investment products. Making these financial companies part of the largest commercial banking services is an important part of the financial system that affects the economy as a whole. 
The best investment banks are large financial institutions that play an important role in facilitating financial funding for the economy. Initial public offerings (IPOs), for example, are opportunities for investors to help companies raise funds. At the same time, they can also acquire shares in the business.

Full Service Investment Bank offers a variety of business and investment services. Many of them also own or work with consumer banks. Most common consumers do not need investment banking services, but for growing businesses and high-value asset owners, these types of banks have their own financial products to meet their needs. And can provide services. Need advice when searching for your product? See the following recommended investment banks.

Investment banks are financial intermediaries that specialize in the sale of securities and the issuance and underwriting of new shares to raise capital financing. Investment banking is a special segment of banking that assists individuals or organizations to raise capital in the main market. In the tea market, new securities are issued and act on behalf of customers, thus playing an important role in the secondary market. They act as intermediaries between issuers of securities and investors, helping new companies go public. Investment banks offer a wide range of financial services, including equity and securities trading, M\&A advisory, leveraged finance by borrowing funds to purchase assets and settlement of acquisitions, and structural reforms to improve corporate structures. The bank conducts new issuances and IPOs to support the listing of new companies, which helps the business to generate maximum profits more efficiently. The investment bank is divided into front office, middle office and back office. Each department is very different, but when a bank makes money, it plays an important role in managing risk and keeping it running smoothly.

\section{Aim of the study}

Regional development encourages communities to improve their economic, social, cultural and environmental well-being by unleashing the full potential of local resources and residents. Regional economic differences pose a threat to Europe's economic development, social ties and political stability. Market processes and policies that have spread prosperity and opportunities are no longer effective enough. Evidence shows that there are several economic clubs in the European region, each with different challenges and opportunities for development. Although regional development is a broad term, it can be considered as a general strategy for closing regional disparities by supporting regional economic activity (creating employment and wealth). Regional development can be, in essence, domestic or international.

This is based on the assumption of perfect competition and perfect factor liquidity, as increased investment in cities and regions in developing countries continues to diminish returns to scale in regions prospering on a large scale for congestion and high land and labor costs. You can get a sense of harvest. . The expected result is the fusion of territories without intervention. However, a combination of empirical evidence and the emergence of competing theories have removed some of the brilliance of the neoclassical approach to economic development.

\section{Literature Review}

(Mertens, D., \& Thiemann, M. 2019) The European Commission European Investment Plan and the ongoing economic crisis have put the state-owned development bank at the center of public and academic debate in Europe again. This document proposes to put the activities of these banks and their recent institutional cooperation in the context of European integration and presupposes a historical perspective on economic governance and development banking in Europe. Most importantly, the European Investment Bank, is being the center of a long-standing political attempt to increase the investment firepower of the European Union. This document, based on detailed process tracking analysis by publicly available data and interview data, has been going on since the late 1980s, reaching a culmination in the policy process after the recent crisis, and depicts the process of institutional innovation and network formation. In conclusion, the current visibility of development banks in Europe follows this and represents the nuclei of European investment countries that are somewhat hidden, but their scope and stability have yet to be determined.

(María del Carmen Valls Martínez, et al 2020) at the end of the 20th century, a new banking model, so-called ethical consumer banking, emerged and became the largest exponent of socially responsible investing. The financial crisis of 2008 created distrust of the existing financial system and as a result, investors began to turn to this new bank, which only invests in ethical activities and products with full transparency, democratic governance, and social and environmental standards. The purpose of this article is to analyze the structure of 
an ethical consumer finance economy, paying attention to liquidity coverage solvency compared to traditional banks. Specifically, it compares the financial statements of Bank Toriodos, a leading European ethical bank belonging to the Global Alliance of Value Banks, with two of each of the major traditional banks in the five European countries it operates. To do this, we apply the mean difference test and ANOVA on a series of financial ratios applying financial and economic analysis to the period from 2015 to 2018 , and finally apply probit regression. The results indicate that ethical banking is growing over traditional banking, with higher liquidity and solvency, but generally speaking, not as profitable. In conclusion, both savings and investors are being assured that their savings are invested in a responsible manner, as well as investing with confidence in ethical banking.

(Goodhart, C., \& Schoenmaker, D. 2016) In the aftermath of the global financial crisis, the market share of US investment banks has risen and the market share of European banks has declined. We present evidence just before the US investment bank acquires pole position from the European Investment Bank. Therefore, while US players became dominant in Europe, China solved the problem itself. Since 2015, China's investment banks have overtaken the positions of US and European Investment Banks in the Asia-Pacific market. Credit evaluation agencies and investment banks are the gatekeepers of the Capital Markets Union. European regulators can effectively oversee the European operations of these US managed players. I will explain the result of the breakfast sheet. On the political front, we suggest that the European Commission must continue the declining banking industry to the strategic sector. The Executive Committee, the European Central Bank and the Bank of England need to jointly develop a strategic agenda for the EU-US regulatory dialogue. Finally, companies rely on investment banks to issue new securities. We cherish the rest of the European Investment Bank by having the largest European companies occupy at least one place in a US-controlled banking syndicate. This can help avoid full reliance on US investment banks.

(Apostoaie, C. M., \& Bilan, I. 2020) Our study aims to quantitatively assess some of the determinants of shadow banking dynamics in the 11 European Union (EU) countries of Central and Eastern Europe (CEE) from 2004 to 2017. will do. Using panel data estimation techniques and quarterly datasets collected from multiple published data sources, we have two other measurements in the shadow banking sector: two dependent variables that correspond to a wide range of measurements. Evaluate the impact of six macroeconomic and financial variables. All non-monetary financial institutions (excluding pension funds under the Insurance Law) and narrow financial institutions (excluding the investment funds mentioned above, excluding money market funds [MMF]). Our findings confirm that shadow banking is sensitive to the overall macroeconomic situation and has a positive impact on economic growth and the expansion of this financial sector. In addition, the demand for funds from institutional investors will increase, and the financial system will evolve further to support the expansion of the shadow banking sector. Also, while investors who find profits in a low interest rate environment turn to shadow banks, the development of the shadow banking sector has revealed that the rest of the financial system complements the development of traditional banks in particular.

\section{EU Policy Approach to global development}

A strong global role requires strong policy coherence in the EU's development approach. According to the World Bank, the COVID-19 crisis has broken global development goals and can put more than 100 million people worldwide in extreme poverty. Therefore, a strong European voice in development is a moral obligation.

Such a position is also in the interests of Europe. Developing countries are struggling with the health and economic consequences of infectious diseases, but existing security threats and challenges have not been mitigated. There are already signs of increasing violence in vulnerable or conflict-stricken areas such as the Sahel and Iraq.

Meanwhile, the devastating impact of climate change on developing countries is calling for Europe to strengthen its international role. We know that European action alone will not change the direction of global warming. After all, Europe's carbon dioxide emissions are less than a third that of Asia. Addressing the impacts of climate change requires reaching across borders, learning lessons, sharing expertise and working with green investors everywhere. A coherent climate strategy should be an important component of an effective European development strategy.

This should allow Europe to think heavily about development and exceed the EU's current four development finance activities. The bloc participates in global companies such as the World Bank, as well as regionally 
focused organizations such as the African Development Bank and the European Bank for Reconstruction and Development. It is also funding development in both countries through the European Investment Bank (EIB) and nationally through institutions such as AgenceFrançaisdeDévelopement.

Europe must continue to engage in all four aspects. But in a world where national interests are increasingly diversified, the EU must also strengthen its strategic autonomy to promote its priorities and values internationally. Strategic issues such as climate change, human rights, changes in global value chains, and migration cannot wait for the United States, China and Russia to act. In addition, unilateral actions by individual EU member states are also insufficiently inefficient and counterproductive for Europe. The

EU must speak with a clear voice, as other global powers are already doing. China not only established the Asian Infrastructure Investment Bank, but also significantly increased the resources and efforts of the China Development Bank, a bilateral development agency, in the Belt and Road Initiative, which was signed by President Xi Jinping. Surprisingly, while China has introduced some restrictions on domestic fossil fuel investment, foreign investment has a notable tendency to finance coal and gas projects. As such, China is opening up its market to Chinese companies, while other global suppliers of clean technology solutions are losing their way.

Meanwhile, the United States, which has been pursuing an introverted "America First" policy under President Donald Trump, has consolidated various institutions under the United States International Development Finance Corporation to strengthen bilateral development activities. If the Paris Agreement and the UN Sustainable Development Goals are to be prevented from slipping into the global agenda, the EU needs to step up its development financing activities. Steps and have been thinking for a long time. Now is the time for Member States to set up and establish such institutions under the roof of the EIB and leverage the assets they have already built together.

The EU Development Bank is swift and important and has an efficient impact on resources. By leaving the blockchain's Minister of Development to the driver's seat and allowing the Ministry of Finance to receive overall supervision, the new agency will be coordinated and transparent in development funding, which was previously very scarce. Will bring a European approach. In addition, the strong governance role of the European Commission and the Agency for Actions outside Europe ensures that banking strategies and all individual projects meet EU development policy objectives from day one.

This new institution does not replace European participation with global and local multilateral banks, it is powerful and does not undermine development institutions in various countries. Rather, its role is to give the EU a strong voice on issues in which Member States share common ambitions that have not been fully considered at global and regional levels, such as supporting the social resilience of vulnerable countries and promoting climate change measures.

In order to fully utilize the richness of the existing European development work, all national development banks and institutions must have the option of participating in the new EU development banks without losing their obligations, or access to the EU, as well as the obligations of autonomous states. means of financing. This could in turn ensure a transparent division of work linking development financing activities at EU and national level.

In addition, activities co-financed by the EU development bank and national development institutions could become subject to an accelerated approval procedure for EU risk-sharing mandates (as is already the case for some EU mandates today). This would significantly increase impact - without requiring any additional resources - by reducing the bureaucracy (and time) involved in allocating these funds.

The EU needs to set a new course for development, and send a strong signal that Europe is ready to play its role in the world. Our history, principles, and ambition demand nothing less.

\section{European economic regional development}

(Beugelsdijk, S., et al 2018) European regional economic development: the role of all factor productivity. local study. This paper documents the fact that large permanent differences in regional economic development in sub-countries of the European Union are likely to be largely attributable to differences in total factor productivity (TFP). This paper applies development accounting techniques to decompose the difference in output per worker in the EU region of 257 into a factor by local ability of a factor of production and a factor 
by TFP. As the analysis shows, the difference in TFP is strongly related to the large economic geography and historical development path even in the country. This suggests limited interregional diffusion of technology and efficient production practices.

\section{Capital Market and economic growth among EU}

(The Economic Growth in the EU 2017) The European Commission's plans to mobilize capital from Europe by launching the Capital Markets Union project, which is expected to be completed by 2019, are heavily dependent on banks due to the nature of the European financial system. The financial crisis that began in 2007 underscores the importance of capital market funding locations. This has had a huge impact on the banking industry and can still be seen today. This article analyzes the relationship between economic growth and several variables that characterize the capital markets of the 28 member states of the European Union. Annual data from 2000-2015 will be used to capture multiple European economic cycles corresponding to each of the 28 countries at the beginning of 2017 (EU accession will occur after 2000) in Central and Eastern European countries. If). We used data that reflected economic growth, the rate of return on the stock market, market capitalization as a percentage of GDP, and the value of equity trading as a percentage of GDP. The analysis begins by running the Pairwise Granger causality test to confirm that there is a causal relationship between the analyzed variables. The results show that the variables that characterize capital markets are causal to economic growth and Granger. It also uses panel data regression to find the relationship between the selected variable and the results obtained. The conclusions indicate whether there is a positive relationship between economic growth over the selected country period and the other three variables. These results show that capital markets are important as a means for European financial companies, as they are directly related to market capitalization (capital market size) and transaction value (a measure of capital market liquidity and activity). Stock market returns are also positively correlated with economic growth, suggesting that the first variable can be used as an indicator of future economic trends. These results are important for users of all sizes, from individual investors and institutional investors (those interested in the development of capital markets and mechanisms). Capital Markets Union Planning and Implementation.

\section{The European Investment Bank's Role in Regional Integration and Development}

(Griffith-Jones, S., \& Tyson, J. 2012) European integration entailed the establishment of a major financial mechanism from the outset. These mechanisms and synthetic loans and transfers were considered both economic and political conditions to make economic integration effective and equitable. This chapter focuses on the European Investment Banking Group (EIB), the instrument of these financing mechanisms, the world's largest development bank. It analyzes key features, functions and evolution, reviews possible lessons for Latin American development banks, particularly Brazil, and examines the creation of Latin American and Caribbean development banks (LACs) owned by Latin American and Caribbean countries. domain. This discussion is placed in a broader context rather than a new vision of Latin America's development strategy.

The creation of the EIB on economic and political grounds is the same as the same trade liberalization and economic integration that occurred in the European Union as a reaction to widely accepted economic analysis, faster overall through economies of scale. It shows that it contributes to growth. Other mechanisms, due to their inherent asymmetry, lead to relatively low rapid growth (or decline) in relatively poor areas. Economic analysis and experience have also shown that private financial markets are incomplete and incomplete. In fact, one of the most serious market failures was raising money for large infrastructure projects. These projects generally generate revenue and take a long time to generate revenue, recognizing the risk of increased risk over time during these periods, as well as for infrastructure projects. It can be longer than the capital or banking market wants, as its characteristics suggest a wide range of political risks. It is defined as a change in price or regulatory structure. Therefore, the comfort provided by public co-financing is important to encourage private investment in infrastructure, or if private investment is totally impossible, public banks and governments invest in infrastructure projects that are developmentally desirable. You need to do or lend. These issues have created theoretically and politically clear cases to deal with such market imperfections through the creation of very large public banks. As we will see, this case is as powerful as it is in Latin America today. 


\section{Conclusion}

There is full fusion or equality at the level of development. There is not. Instead, it is necessary to identify possible short- and medium-term regional development paths with respect to this broad structure. This can specifically judge whether thriving regions are consistently prosperous, and whether non-thriving regions have a chance to converge upwards. Public development banks can play an important role in investments that require scale and long-term financing. This is because some of these investments, especially green infrastructure and energy investments, can be the first to benefit over the long term. Confidence in private investment is promoted through the financing of development banks through the specific financing methods used by the EIB. As discussed, also an example of a place where the EIB is offering valuable lessons is the issuance of long-term 'green' bonds in the country's currency by the Latin American National Development Bank. Also, from a purely commercial standpoint, temporary transparent grants to support the adoption of green technologies that are not yet profitable could ideally be implemented by national and regional development banks. This could include an outpouring of global funding dedicated to bringing such technologies to developing countries. These collaborations with the EIB and the World Bank could be particularly beneficial, benefiting from both investments in the green economy and the resources of subsidies allocated to investments in technology transfer. Therefore, the role of national or regional development banks must be defined in the context of a vision of a development strategy that will lead to more sustainable, equitable and rapid growth. The size, sectoral priorities, and instruments of these development banks should be designed to serve the vision of the development strategy.

\section{References}

1. Apostoaie, C. M., \& Bilan, I. (2020). Macro determinants of shadow banking in Central and Eastern European countries. Economic Research-Ekonomska Istrazivanja, 33(1), 1146-1171. [CrossRef]

2. Asatryan, Z., \& Havlik, A. (2020). The political economy of multilateral lending to European regions. Review of International Organizations, 15(3), 707-740. [CrosRef]

3. Beugelsdijk, S., Klasing, M. J., \& Milionis, P. (2018). Regional economic development in Europe: the role of total factor productivity. Regional Studies, 52(4), 461-476. [CrossRef]

4. Bodenstein, T., Faust, J., \& Furness, M. (2017). European Union Development Policy: Collective Action in Times of Global Transformation and Domestic Crisis. Development Policy Review, 35(4), 441-453. [CrossRef]

5. Bremberg, N. (2020). European Union contested: foreign policy in a new global context. Global Affairs, 6(2), 234-236. [CrossRef]

6. Clifton, J., Díaz-Fuentes, D., \& Revuelta, J. (2014). Financing utilities: How the role of the European Investment Bank shifted from regional development to making markets. Utilities Policy, 29, 63-71. [CrossRef]

7. del Carmen Valls Martínez, M., Rambaud, S. C., \& Oller, I. M. P. (2020). Sustainable and conventional banking in Europe. PLoS ONE, 15(2). [CrossRef]

8. European Investment Bank. [Link]

9. Furness, M., \& Gänzle, S. (2017). The Security-Development Nexus in European Union Foreign Relations after Lisbon: Policy Coherence at Last? Development Policy Review, 35(4), 475-492. [CrossRef]

10. Furness, M., \& Gänzle, S. (2017). The Security-Development Nexus in European Union Foreign Relations after Lisbon: Policy Coherence at Last? Development Policy Review, 35(4), 475-492. [CrossRef]

11. Goodhart, C., \& Schoenmaker, D. (2016). The global investment banks are now all becoming American: Does that matter for Europeans? Journal of Financial Regulation, 2(2), 163-181. [CrossRef]

12. Griffith-Jones, S., \& Tyson, J. (2012). The European Investment Bank and its role in regional development and integration. The Transformations of the International Financial System. Brasília: IPEA. [Link]

13. Griffith-Jones, S., \& Tyson, J. (2013). The European Investment Bank: Lessons for developing countries. WIDER Working Paper, (2013/019), 1-22. [Google Scholar] 
14. Holden, P. (2020). Irreconcilable tensions? The EU's development policy in an era of global illiberalism. Journal of Contemporary European Research, 16(2), 101-119. [CrossRef]

15. Is The Capital Market Important for the Economic Growth in the Eu? (2017). Annals of the University of Oradea: Economic Science, 28(1), 315-324.

16. Kuklinska, K., Wolska, L., \& Namiesnik, J. (2015). Air quality policy in the U.S. and the EU - A review. Atmospheric Pollution Research, 6(1), 129-137.[CrossRef]

17. Mertens, D., \& Thiemann, M. (2019). Building a hidden investment state? The European Investment Bank, national development banks and European economic governance. Journal of European Public Policy, 26(1), 23-43. [CrossRef]

18. Papagianni, G. (2013). Forging an external EU migration policy: From externalisation of border management to a comprehensive policy? European Journal of Migration and Law, 15(3), 283-299. [CrossRef]

19. Pinder, D. A. (1986). Small Firms, Regional Development and The European Investment Bank. JCMS: Journal of Common Market Studies, 24(3), 171-186. [CrossRef]

20. Tuijnman, A. (2009). The education lending policy of the European investment bank. European Journal of Education, 44(1), 111-125. [CrossRef] 